\title{
SERVANT LEADERSHIP TOWARDS THE 21ST RICH MEDIA TECHNOLOGIES AMIDST COVID-19
}

\author{
Sarah V. Ramos \\ University of Southern Mindanao \\ The Philippines \\ (svramos@usm.edu.ph) \\ DOI: https://doi.org/10.22452/jati.vol25no2.3
}

\begin{abstract}
21st-century innovative learning style necessitates thinking skills to develop a curriculum. This study sought to enhance education in terms of using media technologies. This research investigated the experiences of the participants utilising the case study design. The research was made online with the ten (10) participants who underwent distance learning due to COVID-19. The researcher used the instrument which revealed six themes that formed the individual case description. The servant leadership theory was used as a theoretical framework in the analysis. In the context of the curriculum, this study employed online instruction and overall program retention. The curriculum is updated and upgraded in response to the needs of the learners. It was found out that higherorder thinking skills were seen as active learning in terms of instruction and learning efficiency. Consequently, in the context of Servant Leadership, it revealed that one must strive hard to understand employees' perspectives and intentions particularly on their adjustment in utilising high technology demands due to the COVID-19 pandemic impact on education.
\end{abstract}

Keywords: 21st_century rich media technologies, COVID-19 pandemic, servant leadership

\section{Introduction}

Thinking skills have become essential learning to develop an innovative, dynamic worldly economy in the 21st century (Trilling \& Fadel, 2009 as cited in Kanokpermpoon, 2019). This has led to curriculum reforms in different countries like Thailand (Ministry of Education, 2015), Ireland (Dwyer, Hogan \& Stewart, 2014 as cited in Kanokpermpoon, 2019), and Hong Kong (Cheng, 2010 as cited in Kanokpermpoon, 2019) which gives a positive impact on the integration of thinking skills towards technology-enhanced curriculum. Congruently, the 
Department of Science and Technology declared that the readiness of the Philippines is far from being technologically advanced that ranked 83rd out of 138 countries in terms of digital readiness. According to DepEd's ICT Service Director Aida Yuvienco that 26 percent of public schools are connected to the internet, and she pronounced that there are nearly 5000 schools without access to electricity in remote areas (Basu, 2020) where most institutions are experiencing. Thus, it is relevant to recognise the essence of servant leadership due to using the

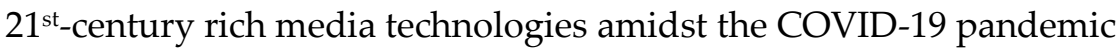

The tiding on the impact of online learning has been an issue because of the abrupt Education transition. Arcilla (2020) mentioned that most parents preferred modular learning for the school year 2020-2021 in DepEd. President Duterte is declaring not to use face-to-face classes until 2021, which is comprised of printed and offline digital modules, radio, and TV-based instruction when the classes will commence. Out of the online learning preferences, 1.4 million parents favored educational TV to be used for instruction, 900,000 parents favored radiobased instruction, and about 500,000 wanted other systems such as face-to-face classes. 1.5 billion students in 165 countries are not enrolled due to the pandemic, COVID-19 as UNESCO (2020) declared. The global academic community was forced to explore the teaching and learning process in which online or distance education is included. This has become challenging for both faculty and students who have to experience economic, emotional, and physical difficulties posed by the illness while doing their obligation to help curb the spread of COVID-19. UNESCO is uncertain for the students who will graduate this year crippled economically by the pandemic. The current crisis is quite essential in the economic impact. The UN Department of Economic and Social Affairs (UN DESA) stated that the global economy may shrink by nearly $1 \%$ by the end of 2020. International Labour Organisation (ILO) declared global unemployment between 5.3 million and 24.7 million. World Trade Organisation (WTO) prospects this year a $13 \%$ to $32 \%$ global trade decline. Hence, HEIs have been dealing with the economic recession considering the employment reduction to enter the job market in a few months, delayed paying fees, inability to grant commitments to publicly fund the institutions and the changes of student behavior due to the modes of the degree program. Moreover, the Commission on Higher Education (CHED) pronounced the 3.2 million college students in the Philippines enrolled for the School Year 2018-2019. But it was then announced that out of the mentioned number of students, $70 \%$ are not able to enroll this year due to COVID- 19 (Romero, 2020).

As online learning and instruction continue to become more prevalent in higher education, servant leaders must better understand online learning that 
needs to address isolation, dissatisfaction with the methodologies to attain positive impact to the school community in general (Joyce \& Brown, 2009 as cited in Oregon, McCoy, \& Johnson, 2018). Thinking skills must be integrated into personal self-development toward the digital demands that everyone is experiencing. In this regard, it is significant to recognise servant leadership that ensures the needs of the institution.

Thus, this present paper unveils thinking skills in using the $21^{\text {st-century }}$ rich media technologies due to COVID-19 as servant leadership towards the reality of school management. It aims to answer how the servant leaders supervise institutions amidst the current pandemic.

\section{Literature Review}

\section{CHED Context Concerning Curriculum}

The Commission on Higher Education (2020) is experiencing difficulties because of the transition and economic fallout brought by the COVID-19. CHED (2020) responded to the dynamic impact of using online instruction in relaying a message. One of the changes is to upgrade the curriculum to active learning required for the 21st century (Lertpaithoon, 2014 as cited in Kanokpermpoon, 2019). Due to boost the school's ability to compete in the global economy, the curriculum must change significantly through distance learning. This has been responded to by reforming the education curriculum concerning the needs of the school community for its improvement.

\section{$21^{\text {st }}$ Century HEI Curriculum}

Higher Education Institutions (HEIs) have a high level of uncertainty due to varied difficulties encountered such as low connectivity (University of the Philippines Los Baňos, 2020). HEIs are mainly responsible for the 21st-century curriculum. This study helps to develop faculty and students to be engaged and encouraged in using the digital medium in global standards. As for its curriculum, Oregon et al. (2018) entailed that digital communication is compulsory for all learners, and when failed to attain the requirement of the course to have a good signal for accomplishing their requirements especially to those who are living in far-flung areas, and there must be a clear and specific instruction in dealing the learners for vivid understanding. 


\section{Thinking Skills}

Thinking skills become notoriously hard in education today due to the pandemic (Seale, 2020). Thinking skills are part of learning to innovate models for education instruction of the 21st-century skills (Trilling \& Fadel, 2009 as cited in Kanokpermpoon, 2019). Thinking skills are difficult to develop especially from the perspective of training and education (Anderson et al., 2001 as cited in Kanokpermpoon, 2019) due to abrupt transition. From a psychological perspective, they are a form of concepts and judgments, engaging tasks grounded with insights and attitudes (Nickson, 2019). Goel (2019) integrated communication as part of thinking in justifying one's position and solving a problem. In the generic definition of thinking, it is a way to vigorously analyse, conceptualise, synthesise and evaluate information from involvement, communication, reflection, or perception (ŽivkoviL, 2016). In conceptualising the aforementioned definition, a person should continuously obtain notions and utilise it systematically in higher-order thinking to become a critical thinker (ŽivkoviL, 2016). This psychological view is regarded as both reflection and assumption, as well as a problem-solving in communication. Moreover, this kind of thinking can be used in conjunction with Bloom's taxonomy educational framework that comprises of knowledge (facts), comprehension (understanding), application (practical use), analysis (critical examination), synthesis (creation), and evaluation (judgment) (Bloom, Engelhart, Furst, Hill, \& Krathwohl, 1956 as cited in University of Texas, 2015). In applying Bloom's taxonomy in several areas in the context of critical thinking in education, it helps the curriculum designers to realise the varied teaching and learning thinking skills.

On contrary, there are several queries on the value of Bloom's Taxonomy in educational practices (Case, 2013 as cited in Kanokpermpoon, 2019). For instance, the study of Case (2013 as cited in Kanokpermpoon, 2019) misunderstood Bloom's taxonomy in mixing categories from lower-order thinking as a precondition for higher-order thinking such as evaluation, analysis, and synthesis. Sugrue (2002 as cited in Kanokpermpoon, 2019) resonates with his misunderstanding of Bloom's taxonomy which he found unacceptable concerning research support because of impractical learning gaps and inconsistency in the application. This resulted to propose alternative taxonomies in bridging gaps of Bloom's taxonomy (Moseley et al., 2004 as cited in Louw, Zimney, Puentedura, \& Diener, 2016). 


\section{$21^{\text {st }}$ Media Richness Technologies}

Technology integration becomes a challenge to any institution that needs technical and peer support (Johnson, Jacovina, Russell, \& Soto, 2016). Media Richness Theory (MRT) examines communication through the use of a certain medium. This theory is interrelated to Computer Media Communication (CMC). Mediums of communications are important to effective communication which can help lessen the distortion and ambiguity of messages as articulated by the organisational scientists Daft and Lengel (1986 as cited in Sturdevant, 2017). This theory is dependent upon the media adapted to time intervals which helps reduced uncertainties (Sun \& Cheng, 2007 as cited in Oregon et al., 2018). Multiple interpretations cause ambiguity with the messages sent to various individuals. Such Daft and Lengel (1986 as cited in Sturdevant, 2017) developed criteria to determine their capacity for processing ambiguous information. These criteria are ranked as the immediacy of feedback, the capability to broadcast using multiple cues, a variety of language, and the personal focus of media. The immediacy of feedback is the ability to increase common understanding and reduce the uncertainty of interaction. The ability to publicise multiple cues is used by both sender and receiver such as the nonverbal modes and words or symbols which are important for transmitting and interpreting communication. Varied notions inculcate a better understanding and less ambiguity of notions and concepts in using natural language. The personal focus of media provides a richer conveyance of the message through emotional infusion and personal feeling. Thus, criteria can be utilised in asynchronous communication media such as video conferencing and face-to-face that provide minimal uncertainty in the messages contained to both high levels of richness and multiple cues. Contrary, asynchronous communication shows a limitation on the use of multiple cues. It also provides higher levels of ambiguity. For instance, this can be done through email or discussion boards.

Media in the online learning environment expands its necessity based on Volery and Lord's (2000 as cited in Sturdevant, 2017) research which keys to efficacious digital learning can be seen on the three variables such as technology, instructor characteristics, and student characteristics. Technology is the way to enhance engagement to the students which helps to decrease vagueness and impart learning. Teachers must obtain an interactive learning environment that fosters interaction. Teachers must be positive and well-versed in communication. Student characteristics must be based on how the students are well-versed and comfortable in the media, and on how the student accessibly used technology in learning. Nonetheless, Volery and Lord's (2000 as cited in Sturdevant, 2017) 
research found out that these three keys are catalysed providing learning satisfaction to become crucial players in learning.

This study explored online learning effectiveness through analysing the effectiveness of a communication channel in employing Media Richness Theory. Thus, this can play important role in developing and implementing online programs when utilising MRT for examining and evaluating educational progress. Kehrwald (2010 as cited in Satar, 2015) stated that teachers and students, who are experiencing practical problems, must consider reducing uncertainties. In this essence, to avoid equivocality and ambiguity for the enhancement of the overall online environment, the utilisation of media-rich modes of communication is a must to implement.

\section{Reality of School Management}

Out of 161 countries, the COVID-19 pandemic worsens billions of children which resulted in a global learning crisis (Saavedra, 2020). Thus, the school management has been an issue due to its effect on great transition. School Management ensures the effectiveness and improvement regarding attaining the school goals. It is a process of determining the human and material sources and identifying priorities needed for the improvement of the institution (Agi \& Yellowe, 2012 as cited in Agi, 2017). In terms of planning the school for its development and improvement, they are useful as a guide for progressive and sustainable schools. The school management develops the quality framework for school governance (Ontario Ministry of Education, 2000 as cited in Agi, 2017). School development requires committed leadership that possesses collective experiences and expertise (National High School Centre, 2013 as cited in Agi, 2017).

The primary focus on the reality of management theory (Beare, Caldwell, \& Millikan, 1989 as cited in Muttaqin, 2016) is to focus on the school environment, curriculum delivery, and parental involvement. Through this development, the school community gives direction to the work of individuals to ensure quality education in terms of academic achievement and holistic development (Agi, 2017).

\section{Servant Leadership}

Fernandez and Shaw (2020) mentioned that school leaders are experiencing unpredictable adaptive challenges due to COVID-19. However, Servant Leadership theory (Greenleaf, 1996) perceives to help and lead to ensure the needs of many in a particular institution. Greenleaf mentioned that the 
bureaucracy has many organisational experiences that could be overcome through practicing servant leadership attributes. There are seven constructs of a virtuous servant leader. Sequentially, they are trust, humility, altruism, agapao love, vision, empowerment, and service. This embodies the theoretical core of Greenleaf's theory (1996 as cited in Janzen, 2018). Similarly, Patterson's (2003 as cited in Wills, 2020) work administered the seven constructs to servant leadership development.

\section{Methodology}

The present study considered how thinking skills could be integrated into online instruction of the 21st-century curriculum in Higher Education Institutions (HEIs), and how the servant leaders supervise the new reality of school management due to the COVID-19 pandemic. This ought to answer the research questions below:

RQ1: What kind of thinking skill does the 21st-century curriculum utilise online instruction amidst COVID-19 pandemic?

RQ2: What are the typical challenges in online classes?

RQ3: How do the servant leaders cope and resolve the identified challenges and difficulties?

RQ4: What kind of virtuous (trust, humility, altruism, agapao love, vision, empowerment, and service) do the servant leaders manifest in the reality of school management?

To comprehensively respond to the research questions, the researcher employed the Servant Leadership Theory. Triangulation was utilised for gathering the data. There were ten (10) randomly selected participants in the present study who served as teachers from Higher Education Institutions having headship designations in which the researcher modified as servant leaders in their respective institutions.

\section{Result and Discussion}

Online instruction is commonly used in teaching to continuously enhance the learning of the students. To determine whether thinking skills have been integrated into the 21st Century Curriculum in using online instruction, the Tables below further illustrate the gathered data from the participants. The participants under investigation are from different Higher Education Institutions (HEIs), practicing headships in their respective work. 
Table 1: Thinking Skills in the 21st Century Curriculum through the Use of Online Instruction amidst COVID-19 Pandemic

\begin{tabular}{|c|c|}
\hline Essential Theme & Thematic Statement \\
\hline $\begin{array}{l}\text { Lowest thinking skills are } \\
\text { incorporated into online } \\
\text { classes }\end{array}$ & $\begin{array}{l}\text { - ....we usually apply to understanding, and then } \\
\text { the lowest part is creating because it does not } \\
\text { apply during online class to us Engineering } \\
\text { faculty since we need actual application. (R\#1) } \\
\text { It can be integrated but with a challenge, since } \\
\text { the lack of physical interaction makes class } \\
\text { activities not monitored/supervised. For doing } \\
\text { the online class, remembering comes first } \\
\text { followed by understanding, analysing, } \\
\text { applying, evaluating, and creating. (R\#4) }\end{array}$ \\
\hline $\begin{array}{l}\text { Higher thinking skills are } \\
\text { congruently incorporated in } \\
\text { supplementing the needs of } \\
\text { the students }\end{array}$ & $\begin{array}{l}\text { - In terms of Bloom's taxonomy, we are usually } \\
\text { applying the creating because it supplements } \\
\text { our needs. However, remembering is the last } \\
\text { one we are using because we are not } \\
\text { memorising, we are just understanding the basic } \\
\text { problem solving and the basic concept in } \\
\text { Mathematics relative to the engineering program. } \\
\text { (R\#2) } \\
\text { Higher thinking skills can integrate if students } \\
\text { are given case analysis. }(\mathrm{R} \# 3)\end{array}$ \\
\hline
\end{tabular}

Lowest Thinking Skills are incorporated into online classes. This is one of the two themes generated from question number one. The participants responded that they usually incorporated lower thinking skills in every online class. The skills mentioned are understanding and remembering which the higher thinking skills are not usually used in instructing online classes. To such a case, one of the participants enumerated the thinking skills usually used as stated:

"For doing the online class, remembering comes first followed by understanding, analysing, applying, evaluating and creating." (R\#4)

In response to lower thinking skills such as remembering, the participant has also integrated other skills in making the class meaningful. As described by Marder (2017) that creativity to recall data and information is what we call remembering. Remembering is a process of committing ideas to memory and a process of recall, understanding, and retention which help the learners to understand a concept (Bilash, 2019). Anderson et al. (2001 as cited in Louw et al., 
2016) stated that varied researchers discovered that lower-order thinking skills are more relevant to learning materials than higher-order thinking skills when utilising the updated Bloom's Taxonomy towards the active program.

Higher thinking skills are congruently incorporated in supplementing the needs of the students. This second theme generated from objective number one is contrary to the first theme since higher-order thinking skills have been used frequently in online classes. Such a response is given below:

"Higher thinking skills can integrate if students are given case analysis." (R\#3)

The aforementioned statement clearly shows the application of higherorder thinking skills specifically in the context of case analysis. St. John's University (2020) affirmed the necessity of higher-order thinking skills in learning which mentioned that it helps students to improve their cognitive ability. These skills help to enhance problem-solving and critical thinking which can be applied to their lives.

Table 2: Typical Challenges in Online Education

\begin{tabular}{|c|c|}
\hline Essential Theme & Thematic Statement \\
\hline Poor online connectivity & $\begin{array}{l}\text { - Poor online connectivity. Having an online class } \\
\text { is uncontrollable especially during exams or } \\
\text { quizzes which teachers must need to understand } \\
\text { the situation with regards to inconvenience. (R\#1) } \\
\text { - Communication barriers like poor internet } \\
\text { connectivity. (R\#2) } \\
\text { Poor internet connectivity especially for the } \\
\text { students who are living on the outskirts. (R\#3) }\end{array}$ \\
\hline Commitment of the students & $\begin{array}{l}\text { - It is not also accessible to everyone, and the } \\
\text { internet is very expensive. We also still need } \\
\text { experience, especially when having laboratories. } \\
\text { Sometimes, teachers cannot accommodate all the } \\
\text { questions raised by the students. The online class } \\
\text { is hard without the students' full commitment. } \\
\text { It is better to teach the conventional class. (R\#2) } \\
\text { Most of the challenges are because of the facilities, } \\
\text { such as internet connectivity (for teachers and } \\
\text { students) and the limited technical capacity of the } \\
\text { students or the teacher. Another is the } \\
\text { commitment of the students to be in the online } \\
\text { class. (R\#4) }\end{array}$ \\
\hline
\end{tabular}


Poor online connectivity. This is the first theme that appeared as a typical challenge in online education. The participants expressed their untoward experiences such internet is uncontrollable which can create inconvenience and barriers in communication especially those who are living in far-flung areas where there is no internet connectivity. To cite vivid response:

"Poor internet connectivity especially for the students who are living in the outskirts." (R\#3)

The statement illustrates the problem of online classes which the internet is essential in the learning process. However, this must be taken into consideration particularly for those who cannot use the internet due to poor connectivity. Philippine Daily Inquirer (2020) confirmed the worries that learners have experienced due to slow internet connectivity. Students in the Philippines petitioned the bearing of online classes due to the poor connectivity as addressed to the CHED chair, Prospero De Vera.

Commitment to the students. This is the second theme generated in the second research question. The participants expressed that students must be committed to online classes which they need to have good connectivity and a well-driven interest to learn. As stated by one of the respondents:

"Most of the challenges are because of the facilities, such as internet connectivity (for teachers and students) and the limited technical capacity of the students or the teacher. Another is the commitment of the students to be in the online class." (R\#4)

The statement indicates the significance of the commitment of the students which they need to cooperate with the teacher despite the barriers encountered. Similarly, Southern Adventist University (2020) mentioned that students must consistently commit themselves towards social, academic, personal, spiritual, and corporate responsibilities.

Table 3: Cope and Resolve the Identified Challenges and Difficulties

\begin{tabular}{|l|l|}
\hline \multicolumn{1}{|c|}{ Essential Theme } & \multicolumn{2}{|c|}{ Thematic Statement } \\
\hline Utilise innovative and & $\bullet \quad \begin{array}{l}\text { Employ another method may be a modular type } \\
\text { upgraded materials }\end{array}$ \\
$\begin{array}{l}\text { or leniency, provided as to the MUST } \\
\text { attendance in Livestream classes. (R\#3) } \\
\text { The coping mechanism is to include critical }\end{array}$ \\
\hline
\end{tabular}




\begin{tabular}{|c|c|}
\hline & $\begin{array}{l}\text { thinking materials (as for me, watch } \\
\text { documentaries). (R\#4) } \\
\text { Also, throwing to them some activities that } \\
\text { will make them work, even if online, like } \\
\text { searching the web, or going into trends, like } \\
\text { making blogs. As per connectivity issues, I go } \\
\text { for what students can afford to have to connect } \\
\text { to their classes (messenger or email for example. } \\
\text { (R\#4) }\end{array}$ \\
\hline Time management & $\begin{array}{l}\text { - Before answering, students must prepare their } \\
\text { modules and materials for } 30 \text { minutes or one } \\
\text { hour to be used in examinations or quizzes. } \\
(\mathrm{R} \# 1) \\
\text { Doing memos to keep me updated. I read it } \\
\text { daily which can also help the students to } \\
\text { practice solving. I use the website as the } \\
\text { scaffold of learning. (R\#2) }\end{array}$ \\
\hline
\end{tabular}

Utilise innovative and upgraded materials. This emerged as one of the essential themes from question number three. Online activities through using upgraded materials must be utilised to enrich active learning. There are new varied ways of utilising online classes like blogs and Livestream classes. For instance:

"Also, throwing to them some activities that will make them work, even if online, like searching the web, or going into trends, like making blogs. As per connectivity issues, I go for what students can afford to have to connect to their classes (messenger or email for example)." (R\#4)

The statement encourages others to utilise innovative activities to make the learners more creative. Quality output is possible through utilising upgraded and updated sites useful to education. Davis (2017) stated the positive impact on innovative teaching strategies which can encourage students to scrutinise contents in the subject matter.

Time management. The second theme is extracted from the participants in responding to research question number three on the cope and resolve the identified challenges and difficulties. The theme manifests that online users in education must be responsible for managing their time like rendering a specific 
time to thrive to work on the designated tasks. Another is to manage learning by practicing how to practice or study daily. As expressed:

"Before answering, students must prepare their modules and materials 30 minutes or one hour to be used in examination or quizzes." (R\#1)

The response shows the preparedness of the learners in learning online that they need to consider how to manage their time effectively to cope up and to respond positively. As indicated, there is a specific time imposed that characterises time cautiousness. Marie (2020) mentioned that practicing good time management habits can help tasks seem more productive and organised, and less daunting.

Table 4: Kinds of Virtuous the Servant Leaders Manifest on the Reality of School Development

\begin{tabular}{|l|l|}
\hline \multicolumn{1}{|c|}{ Kinds of Virtuous } & \multicolumn{1}{|c|}{ Statement } \\
\hline Vision & $\begin{array}{l}\text { I think the institution must think of a better solution } \\
\text { through updating and accumulating the vision and } \\
\text { mission of the school, incorporating the innovative } \\
\text { and creative standards by using high technologies } \\
\text { which necessitate its demand to protect the school } \\
\text { community from the COVID-19 pandemic. (R\#1) }\end{array}$ \\
\hline Empowerment & $\begin{array}{l}\text { I feel that it is significant to be associated with } \\
\text { innovative actions that should push us through by } \\
\text { moving forward. Hence, leaders must have the } \\
\text { willingness to take everything for the goodness of } \\
\text { the institution. This has led me to give a solution to } \\
\text { this unexpected predicament. (R\#4) }\end{array}$ \\
\hline I want to help the school by serving them. I want to \\
serve by building strong professional communities \\
and managing the school in strategic decisions \\
especially now having this COVID. Thus, teachers \\
need to explore and join conferences for their \\
professional growth that qualifies them to 21 st \\
century standards on education. (R\#3)
\end{tabular}

Vision. This is the first statement revealed as a servant leader must possess. This recognised that as a servant leader, one must have a clear vision, as well as a mission through updating its content since high technologies in 
education are well demand to prevent face-to-face interactions due to COVID-19. As stated:

"I think the institution must think a better solution through updating and accumulating the vision and mission of the school, incorporating the innovative and creative standards by using high technologies which necessitate its demand to protect the school community from COVID-19 pandemic." (R\#1)

The aforementioned statement highlighted the importance of the vision and mission of the school. Ketchell (2018) stated that a vision must indicate the priorities and purpose of what the students should learn. This is a reliable representation of what the school must stand for.

Empowerment. The second statement from research question number four shows empowerment as the servant leader strongly declared the courage to move forward to innovative actions for the goodness of the institution. Such a statement is:

"I feel that it is significant to be associated with innovative actions that should push us through by moving forward. Hence, leaders must have the willingness to take everything for the goodness of the institution. This has led me to give a solution with this unexpected predicament." $(\mathrm{R} \# 4)$

The statement shows empowerment which a leader must attain in times of this catastrophe. Lynch (2015) encouraged leaders to be empowering which he mentioned that through empowerment, it increases motivation among subordinate $\backslash \mathrm{s}$ as they set out their organisational goals.

Service. The third statement shows the virtuousness of serving the school community. The servant-leader shows concern by helping the school community especially on the professional growth of the teacher into the digital world of teaching like joining a conference. As stated:

"I want to help the school by serving them. I want to serve by building strong professional communities and managing the school in strategic decisions especially now having this COVID. Thus, teachers need to explore and join conferences for their professional growth that qualifies them to $21^{\text {st }}$ century standard on education." (R\#3) 
The above statement manifests a servant leader who transpires service towards school development. Zhou, Chan, and Mickleborough (2015) concurred that a leader must possess a positive perception in modern society to serve others more effectively.

\section{Implication}

The reality of school development through the supervision of the servant leaders in relative to thinking skills in using the $21^{\text {st }}$-century rich media technologies due to COVID-19 implies the following:

- The management must upgrade teaching style through the use of the demand technologies in the education curriculum.

- Due to the poor knowledge of online classes, it is essential to adjust the teaching procedure considering balanced thinking skills which depend on the knowledge level of the students to ensure the effectiveness of teaching information.

- Teaching online must corporate the principle of sufficient support.

- Contingency plan preparation is significant to address possible problems of the online education platform in making a curriculum.

- The virtuousness of servant leadership must be holistically adapted to the school management in light of their career field.

\section{Conclusion}

Thinking skills integrated into the 21st-century curriculum through the use of online instruction depends mainly on the course or the pedagogical approach used by the teacher. If the teacher uses methodologies that would stir up the mind of the learners, then most probably HOTS will be activated. On one hand, if the teacher uses activities/instructional methods that are inclined to simply remembering or understanding only, then not higher-order thinking skills might be activated.

In place of the typical challenges in the conduct of online classes, there are several challenges. First, some students do not have access to technology that will help them join online classes. Because of this, students are limited in terms of the learning platform that they could have to go with the flow of the new educational normalcy. Second, some teachers might have the not proper training to conduct computer-mediated pedagogy. With the lack of skills, the quality of instruction is at stake. Third, actual classroom interaction could not be equated to online interaction. Whilst the advancement of technology has brought so much 
convenience to many, it must be taken into account that firsthand experience of things is still the best for learners. Hence, actual classroom interaction could have been more effective in providing genuine learning opportunities for students.

In light of the coping mechanism for the challenges and difficulties encountered. As a servant leader of a higher educational institution (HEI), several professional opportunities have been provided to make sure that teachers are equipped with the skills and literacies needed to teach online. Thus, teachers must grab all these opportunities. Another would be to supply themselves with the needed resources such as the technology so that teachers may be capacitated to adapt to this new normal. However, it does cost something; so it is just ordinary for an educator to invest in these things because all these will be used for something purposeful- to educate the learners.

In connection with the virtuous servant leaders on the reality of school development, servant teachers manifest mostly on vision, empowerment, and service. Vision manifests to update its content since high technologies in educations are in demand to prevent face-to-face interactions due to COVID-19. Empowerment shows strong courage to move forward to innovative platforms for the goodness of the institution. Services deals with the concern of helping the school community especially on the professional growth of the teacher into the digital world of teaching. Notwithstanding, a servant leader should characterise these kinds of virtuousness in leading and managing a particular institution.

\section{References}

Agi, U. K. (2017). School development planning: A strategic tool for secondary school improvement in Rivers State, Nigeria. Journal of the International Society for Teacher Education, 21(1), 88-99.

Agi, U. K., \& Yellowe, A. N. (2012). Administrative strategies for achieving quality assurance in secondary education in Nigeria. Research in Education, 18(1), 126-130.

Anderson, L. W., Krathwohl, D. R., Airasian, P. W., Cruikshank, K. A., Mayer, R. E., Pintrich, P. Raths, J. \& Wittrock, M. C. (Eds.). (2001). A taxonomy for learning, teaching and assessing: A revision of Bloom's taxonomy for educational objectives. New York: Addison Wesley Longman, Inc.

Arcilla, J. (2020). DepEd: Most parents prefer modular learning. The Manila Times.

Retrieved

from

https://www.manilatimes.net/2020/07/31/news/national/deped-mostparents-prefer-modular-learning/748207/ 
Basu, M. (2020). The Philippines gets serious about connecting its schools. GovInsider. Retrieved from https:/govinsider.asia/innovation/thephilippines-gets-serious-about-connecting-its-schools/

Beare, H., Caldwell, B., \& Millikan, R. (1989). Creating an excellent school: Some new management techniques. London: Routledge.

Bilash, O. (2019). Understanding and remembering. Best of Bilash. Retrieved from

https://sites.educ.ualberta.ca/staff/olenka.bilash/Best\%20of\%20Bilash/remem bering.html

Bloom, B. S., Engelhart, M. D., Furst, E. J., Hill, W. H., \& Krathwohl, D. R. (1956). Taxonomy of educational objectives: The classification of educational goals by a committee of college and university examiners (Handbook I: Cognitive domain). New York: Longmans Publishing.

Case, R. (2013). The unfortunate consequences of Bloom's taxonomy. Social Education, 77(4), 196-200.

CHED. (2020). COVID-19 updates. Commission on Higher Education (CHED)'s website. Retrieved from https://ched.gov.ph/covid-19-updates/

Cheng, V. M. Y. (2010). Teaching creative thinking in regular science lessons: Potentials and obstacles of three different approaches in an Asian context. Asia-Pacific Forum on Science Learning and Teaching, 11(1).

Daft, R. L., \& Lengel, R. H. (1986). Organizational information requirements, media richness and structural design. Management Science, 32, 355-368.

Davis, J. (2017). Innovative teaching strategies that improve student engagement. Association for Middle Level Education. Retrieved from https://www.amle.org/BrowsebyTopic/WhatsNew/WNDet/TabId/270/ArtMI D/888/ArticleID/876/Innovative-Teaching-Strategies-that-Improve-StudentEngagement.aspx

Dwyer, C. P., Hogan, M. J. \& Stewart, I. (2014). An integrated critical thinking framework for the 21st century. Thinking Skills and Creativity, 12, 43-52.

Fernandez, A. A., \& Shaw, G. P. (2020). Academic leadership in a time of crisis: The Coronavirus and COVID-19. Journal of Leadership Studies, 14(1), 39-45. Retrieved from https://onlinelibrary.wiley.com/doi/10.1002/j1s.21684

Goel, S. (2019). Critical thinking: A few perspectives. Retrieved from https://goelsan.wordpress.com/2019/09/26/critical-thinking-a-fewperspectives/

Greenleaf, R. K. (1996). On becoming a servant-leader. San Francisco: Josey-Bass Publishers.

Janzen, E. (2018). Servant theory page. WikiSpaces. Retrieved from https://wikispaces.psu.edu/display/P5PFLD/SERVANT+Theory+Page 
Johnson, A. M., Jacovina, M. E., Russell, D. G., \& Soto, C. M. (2016). Challenges and solutions when using technologies in the classroom. ERIC: Institute of Education Sciences' website. Retrieved from https://files.eric.ed.gov/fulltext/ED577147.pdf

Joyce, K. M., \& Brown, A. (2009). Enhancing social presence in online learning: Mediation strategies applied to social networking tools. Online Journal of Distance Learning Administration, 12(4).

Kanokpermpoon, M. (2019). Thinking skills in practice: A case study of an English curriculum at a Thai University. LEARN Journal: Language Education and Acquisition Research Network, 12(2), 49-63.

Kehrwald, B. A. (2010). Being online: Social presence as subjectivity in online learning. London Review of Education, 8(1), 39-50. doi:10.1080/14748460903557688

Ketchell, M. (2018). School vision and mission statements should not be dismissed as empty words. The Conversation. Retrieved from https://theconversation.com/school-vision-and-mission-statements-shouldnot-be-dismissed-as-empty-words-97375

Lertpaithoon, S. (2014). Thammasat University: A QS showcase profile of Dr Somkit Lertpaitoon, professor of law and rector of Thammasat University. In C. Tabatabaei (Ed.), QS showcase 2015 (pp. 126-127). Singapore: QS Asia Quacquarelli Symonds Pte Ltd.

Louw, A., Zimney, K., Puentedura, E. L., Diener, I. (2016). The efficacy of pain neuroscience education on musculoskeletal pain: A systematic review of the literature. Physiotherapy Theory and Practice, 32(5), 332-355. Retrieved from http://accurateclinic.com/wp-content/uploads/2016/03/The-efficacy-of-painneuroscience-education-on-musculoskeletal-pain-A-systematic-review-ofthe-literature.pdf

Lynch, M. (2015). Empowering leadership behavior in schools: Lessons learned from the business sector. The Edvocate. Retrieved from https://www.theedadvocate.org/empowering-leadership-behavior-inschools-lessons-learned-from-the-business-sector/

Marder, E. (2017). The importance of remembering. eLife, 6. Retrieved from https://www.ncbi.nlm.nih.gov/pmc/articles/PMC5577906/

Marie, N. (2020). Benefits of time management. TimeCenter's website. Retrieved from https://www.timecenter.com/articles/benefits-of-time-management/

Ministry of Education. (2015). Education for all 2015 national review report: Thailand. UNESCO. [PDF file]. Retrieved from http://unesdoc.unesco.org/images/0022/002298/229878E.pdf 
Moseley, D., Baumfield, V., Higgins, S., Lin, M., Miller, J., Newton, D., Robson, S, Elliot, J. \& Gregson, M. (2004). Thinking skill frameworks for post-16 learners: An evaluation. A research report for the Learning and Skills Research Centre [PDF file]. ERIC: Institute of Education Sciences' website. Retrieved from http://files.eric.ed.gov/fulltext/ED508442.pdf

Muttaqin, T. (2016). Management of change and school improvement. Retrieved from

https://www.researchgate.net/publication/292993426_Management_of_Chan ge_and_School_Improvement

National High School Centre. (2013). High school improvement process. United Kingdom Department of Education's website. Retrieved from http://www.deni.gov.uk/03-schools-schoolimprovement-programme-school development-planning pg.htm

Nickson, C. (2019). Cognitive theory of multimedia learning. Life in the Fastlane's website. Retrieved from https://litfl.com/cognitive-theory-ofmultimedia-learning/

Ontario Ministry of Education. (2000). EQAO guide to school and board improvement planning: A handbook for school and board leaders. Retrieved from http://www.misalondon.ca/PDF/BIP/EQAO_Guide_To_BIP.pdf

Oregon, E., McCoy, L., Johnson, L. (2018). Case analysis: Exploring the application of using rich media technologies and social presence to decrease attrition in an online graduate program. ERIC: Institute of Education Sciences' $\quad$ website. Retrieved from https:/files.eric.ed.gov/fulltext/EJ1186019.pdf

Patterson, K. A. (2003). Servant leadership: A theoretical model. Doctoral thesis, Graduate School of Business, Regent University, Virginia Beach, United States.

Philippine Daily Inquirer. (2020). Students worry about online learning due to slow PH internet. Retrieved from https://newsinfo.inquirer.net/1267743/studentsworry-about-online-learning-due-to-slow-ph-internet

Romero, P. (2020). College enrollment may plunge by up to 70 percent, officials warn. One News. Retrieved from https://www.onenews.ph/collegeenrollment-may-plunge-by-up-to-70-percent-officials-warn

Saavedra, J. (2020). Educational challenges and opportunities of the Coronavirus (COVID-19) pandemic. World Bank Blogs. Retrieved from https://blogs.worldbank.org/education/educational-challenges-andopportunities-covid-19-pandemic 
Satar, H. M. (2015). Sustaining multimodal language learner interactions online. Calico Journal, 32(3). Retrieved from https:/journals.equinoxpub.com/index.php/CALICO/article/view/26508

Seale, C. (2020). The case for critical thinking: The COVID-19 pandemic and an urgent call to close the critical thinking gap in education. Forbes. Retrieved from https://www.forbes.com/sites/colinseale/2020/04/10/the-case-forcritical-thinking-the-covid-19-pandemic-and-an-urgent-call-to-close-thecritical-thinking-gap-in-education/?sh=27ec408e7b72

Southern Adventist University. (2020). Student commitment. Retrieved from https://www.southern.edu/undergrad/campus-life/studentcommitment.html

St. John's University. (2020). Importance of high order thinking skills. Digication. Retrieved from https://stjohns.digication.com/edu_1002_kim/Importance_of_Higher_Order_ Thinking_Skills_in_clas

Sturdevant, G. (2017). Reducing equivocality and uncertainty on Facebook: Examining the level of "richness" Cues in Facebook features. Master's dissertation, Department of Communication Studies, California State University, Sacramento, United States. Retrieved from http://dspace.calstate.edu/bitstream/handle/10211.3/194557/Giselle\%20Sturd evant $\% 20$ Thesis\%20Final.pdf?sequence $=1$

Sugrue, B. (2002). Problems with Bloom's taxonomy [PDF file]. Retrieved December 29, 2015, from https://eppicinc.files.wordpress.com/2011/08/sugrue_bloom_critique_perfxp rs.pdf

Sun, P., \& Cheng, H. K. (2007). The design of instructional multimedia in elearning: A media richness theory-based approach. Computers $\mathcal{E}$ Education, 49(3), 662-676. doi:10.1016/j.compedu.2005.11.016

Trilling, B., \& Fadel, C. (2009). 21st century skills: Learning for life in our times. San Francisco: John Wily \& Sons.

UNESCO. (2020). COVID-19 and higher education: Learning to unlearn to create education for the future. Academic Impact. Retrieved from https://academicimpact.un.org/content/covid-19-and-higher-educationlearning-unlearn-create-education-future

University of Texas. (2015). Blooms taxonomy, learning objectives and higher order thinking. Retrieved from https://www.unthsc.edu/center-forinnovative-learning/blooms-taxonomy-learning-objectives-and-higherorder-thinking/ 
University of the Philippines Los Baňos. (2020). CHED chair, HEI heads discuss grad educ amid COVID-19. Retrieved from https://uplb.edu.ph/academic/ched-chair-hei-heads-discuss-grad-educamid-covid-19/

Volery, T. \& Lord, D. (2000). Critical success factors in online education. Retrieved from https://www.researchgate.net/publication/225157840_Critical_success_factor s_in_online_education

Wills, A. L. (2020). Phenomenological study on the impact of servant leadership for establishing a culture of high performance as perceived by middle school principals. Doctoral thesis, Department of Organizational Leadership, Brandman University, Irvine, United States. Retrieved from https://digitalcommons.brandman.edu/edd_dissertations/351/

Zhou, C., Chan, B., \& Mickleborough, N. (2015). Why is service leadership important in higher education? In D. T. L. Shek, \& P. Chung (Eds.), Promoting service leadership qualities in university students: The case of Hong Kong (pp. 135-138). Singapore: Springer. Retrieved from https://link.springer.com/chapter/10.1007/978-981-287-515-0_9

ŽivkoviE, S. (2016). A model of critical thinking as an important attribute for success in the $21^{\text {st }}$ century. Procedia-Social and Behavioral Sciences, 232, 102108. from https://www.sciencedirect.com/science/article/pii/S1877042816312666 